\title{
THE RESEARCH OF LICHENIZED FUNGI IN HUNGARY
}

\author{
EDIT FARKAS and L. LÔKÖS
}

\author{
Institute of Ecology and Botany, Hungarian Academy of Sciences, Vácrátót, and Department of Botany, \\ Hungarian Natural History Museum, Budapest, Hungary
}

\begin{abstract}
A brief historical account on the Hungarian lichenology is given in three stages. The early stage involves the oldest collections and the lichenological activity of F. Hazslinszky. In the mid-stage a separate, independent lichen collection was established in the Natural History Museum, and a rapid development of floristical and taxonomic research took place. Recent lichenological research in Hungary follows several fields: taxonomy, biogeography, bioindication and ecophysiology.
\end{abstract}

\section{The early stage of Hungarian lichenology}

The first signs of the interest on lichens in Hungary are realized in the oldest herbarium specimens (Cetraria islandica, collected by H. J. N. Crantz in 1762, and Cladonia rangiferina, Peltigera leucophlebia, collected by J. J. Winterl in 1766 in the Alps) kept in the Hungarian Natural History Museum (Budapest). These collections were established in the era of the Swedish doctor, Erik Acharius (1757-1819), who is called "the father of lichenology", because he gave the basic methods for study and classification of lichens (Acharius [1]).

The academician, teacher and polymath Frigyes Hazslinszky [2] published the first detailed lichen flora of the Carpathian Basin based on the results of his own microscopic studies and field experience accummulated in ca 50 years. He also studied and reviewed the herbarium specimens of Lumnitzer, Rochel, Kitaibel, Sadler, Bothar, Jermy, Kalchbrenner, Borbás, and Lojka. Chemical characters and spot reactions were regarded unreliable by him, thus he followed the Körber's system as well as his own concepts. Together with the most valuable, earlier botanical collections (Crantz, Kitaibel, Sadler, Lumnitzer, Albach, Haynald, Lojka) Hazslinszky's lichens were also placed to the museum.

EDIT FARKAS

Institute of Ecology and Botany, Hungarian Academy of Sciences

Alkotmány u. 2-4, H-2163 Vácrátót, Hungary

LÁSZLÓ LÕKÖS

Department of Botany, Hungarian Natural History Museum

P.O. Box 222, H-1476 Budapest, Hungary 


\section{The mid-stage of Hungarian lichenology}

The progress of Hungarian lichenology cannot be separated from the history and development of the Hungarian Natural History Museum, Budapest (Rajczy and Buczkó [3]).

A separated, independent "Collectio Lichenum" within the Natural History Museum was founded only in 1909, several decades after Hazslinszky's work. The lichenological literature was relatively well concentrated here and microscopes indispensable for the scientific study were also available. Therefore the curators (Gy. Timkó, V. Gyelnik, Ö. Szatala) of the lichen herbarium were the first professional lichenologists in Hungary (for more details see Verseghy [4]). They could devote most of their time to the scientific investigation of lichens both in the field and in the herbarium. Their comparative, mainly morphological studies resulted in the description of several new species. Gyelnik (1906-1945) himself described ca 1,300 new taxa (among them 264 new species). From his descriptions it is clear that he applied the usual chemical spot reactions (K, I and C) regarding them of great importance in taxonomy. Szatala (18891958) published 583 new names (among them 73 new species). He prepared the second lichen flora of the Carpathian Basin (unfortunately only three parts were published because of his death).

The diversity of lichens is so high that recently ca 13,500 species is known worldwide and the number of possibly existing species is estimated as much higher (ca 20,000) (Hawksworth et al. [5]: 247). The main purpose of the first lichenologists was the description of these variable organisms. The Hungarian lichenologists followed the accummulated taxonomic and systematic knowledge of the world, corresponding and exchanging lichen specimens with the greatest specialists of their age (e.g. A. Zahlbruckner, E. A. Vainio, H. Magnusson).

Klára Verseghy (1930-) was the first curator of the lichen herbarium who did also, but more than floristics (Bakony, Balaton-felvidék, Hortobágy NP, Kiskunság NP, Ôrség, Vendvidék, Villányi-hegység, Zempléni-hegység) and taxonomy (Caloplaca, Gasparrinia, Ochrolechia, Squamaria) before she wrote the synthesis of her 35 years in lichenology, The handbook of the lichen flora of Hungary [6], containing 715 species from Hungary. She participated in the research project of IBP. She measured the production of Cladonia species of Bugac, Csévharaszt (Kiskunság) in the 1970s. Together with Edit Láng she founded the Hungarian lichen ecophysiological research. Later on Verseghy led air pollution investigations in Budapest. Her students carried out lichen mapping and heavy metal measurements on transplanted lichens (Verseghy and Farkas [7], Farkas et al. [8]).

Ferenc Fóriss (1892-1977) became famous for his enormous collecting activity, almost 40,000 specimens over 25 years, 15,000 records of ca 1,400 taxa only from the Bükk Mts (unpublished). László Gallé's (1908-1980) greatest and also internationally important work is the lichen coenological system of Hungary (Gallé [9]), containing 47 associations. Anna Kiszely-Vámosi (1935-) made the lichen flora of Mátra and Bükk Mts better known. Péter Solymosi (1945-) made lichen floristical research in the Gerecse, Vértes and Buda Mts, along the Danube, and he also used lichens as bioindicators of air 
pollution. Tamás Kiss (1953-) studying this problem in Szombathely and its surrounding area established a life strategy system for lichens in West Hungary.

\section{Recent topics of lichenological research}

The recent lichenological research is even more specialized than that of the 1970s and early 1980s, follows several research lines and has been carried out in various institutions: Institute of Ecology and Botany, Hungarian Academy of Sciences (Vácrátót), Department of Botany, Hungarian Natural History Museum (Budapest), Department of Plant Taxonomy and Ecology, Eötvös Loránd University (Budapest), Department of Botany and Plant Physiology, University of Agricultural Sciences (Gödöllô), Eszterházy Teachers' Training College (Eger), Aggtelek National Park.

Lichens as indicators of air pollution were applied in various investigations (mapping, SEM-EDXRA, photoregistration of permanent quadrats) at the Budapest agglomeration area and at the Pilis and Visegrád Mts (Farkas [10]). It was proved that lichens are sensitive orgarnisms to the quality of environmental conditions, especially to air pollution level and the corresponding meso- and microclimatic changes. The occurrence and distribution of Lecanora conizaeoides and several other toxitolerant and rare species were shown on ca 200 maps. For bioindication purposes the study of the gonidial layer was suggested for Hypogymnia physodes samples by SEM-EDXRA. The permanent quadrat investigations presented considerable differences between the percentage cover of lichen thalli (H. physodes) on moderately polluted and control sites.

Zoltán Tuba and Zsolt Csintalan applied lichen samples for the bioindication of air pollution from industrial sources and the traffic near agricultural areas.

Lichen mapping studies were continued later on Hungarian and European level (also as a part of the International Lichen Mapping Project). Farkas and Lôkös [11] prepared the European distribution maps of the terricolous Cladonia magyarica, a Pannonian endemism and a rare loess inhabiting lichen species, Solorinella asteriscus. Half of the species involved in the ILM Project were extinct from the Hungarian flora, other data documented, that distribution patterns of lichens in Hungary is insufficiently known. Also these results inspired the preparing of a preliminary list of rare and endangered lichens of Hungary (Lôkös and Tóth [12]). Surveys on the flora and fauna of the Hungarian National Parks (e.g. Kiskunság, Bükk, Aggtelek) also included lichen inventories carried out by Lôkös since 1985. From these and several additional, smaller areas approx. 50 lichen species new for Hungary were detected in the last decade. On the basis of the old and new distribution patterns of the species, the amount and trend of the air pollution can be considered. A computerized database system for the present ca 30,000 records and a mapping application for the distribution analyses were organized, elaborated and managed in the Hungarian Natural History Museum.

The maintenance of the tropical biodiversity is essential for the future of the biosphere. Tropical lichenological research is a little contribution to this problem. The extended field work of Tamás Pócs, Attila Borhidi and partly by Edit Farkas resulted in collections of tropical (mainly Tanzanian and Cuban), mainly leaf-inhabiting lichens. New 
species of epiphyllous lichens were described from these collections by Edit Farkas and Antonín Vezda. The bibliography and checklist of foliicolous lichens were compiled (Farkas [13, 14]) and regularly updated (Farkas and Sipman [15, 16]). The first international IAB and IAL Symposium on foliicolous cryptogams (Eger, Hungary, 1995) was initiated and organised by Edit Farkas (Farkas and Pócs [17]). It served the better understanding of the natural ecosystems in the tropical rainforests.

In 1994 a complex biodiversity study started on corticolous and foliicolous representatives of both Hungarian and tropical Bacidia s. str. and related crustose genera (Farkas et al. [18]). HPTLC is introduced for chemical analysis of Bacidia species.

The research line of Klára Verseghy and Edit Láng studying various aspects (drought-tolerance, light-shade conditions, etc.) of autecology and ecophysiology of lowland Cladonia species is continued by Katalin Mázsa (Verseghy et al. [19]) and Zoltán Tuba and their colleagues. Recently a new field of science, synphysiology was outlined by Tuba et al. [20] using also lichens in the experimental basis for the arguments.

An increasing worldwide interest in lichenology is reflected in the number of participants of the symposia of the International Association for Lichenology: IAL Symposium of Tropical Lichenology, London (1989) - ca 60 participants, IAL 2, Båstad (1992) - ca 230 participants, IAL 3, Salzburg (1996) - ca 350 participants.

Fortunately more and more students become interested in the study of lichens also in Hungary, since there is a lot more to learn about lichens.

Lichen substances are analyzed routinely in several institutions of the world, even new substances are described every year. In Hungary HPTLC is introduced recently for chemical analysis of only a few lichen substances (Farkas et al. [18]).

There are successful lichen culture experiments in some institutes in the United States and Europe. No similar experiments exist in Hungary.

The first seminar on molecular studies of lichens was held in Graz between 11-15 August, 1998. In Hungary no molecular research of lichens has been started.

Lichenology in Hungary is still in a descriptive phase. As in the past the lichenologists take great efforts in following the results of the world's lichenologists and only in rare minutes are at least at the international level. A continuous activity is necessary and a hope for increasing possibilities of the forthcoming lichenologist generations.

Acknowledgements Several results achieved are due to the grants by the Hungarian Research Found (OTKA T000939, T000941, T013275, T030209) and the Postdoctoral Fellowship Grant of the Royal Society, London, 1992.

\section{REFERENCES}

1. Acharius,E.: Methodus Lichenum. Stockholmiae. 1803.

2. Hazslinszky,F.: The lichen flora of The Hungarian Empire. (in Hungarian) K M Term Tud Társ, Budapest. 1884. pp. 304. 
3. Rajczy,M., Buczkó,K. (eds): 125 years of the Botanical Department of the Hungarian Natural History Museum. Hungarian Natural History Museum, Budapest. 1996. pp. 64.

4. Verseghy,K.: Die Lichenologen Ungarns. Feddes Repert. 68(2), 107-129 (1963).

5. Hawksworth,D.L., Kirk,P.M., Sutton,B.C., Pegler,D.N.: Ainsworth \& Bisby's dictionary of the Fungi. 8th edn. IMI, CAB International. 1995. pp. 616.

6. Verseghy, K.: The handbook of the lichen flora of Hungary. (in Hungarian) Magyar Természettudományi Múzeum, Budapest. 1994. pp. 415.

7. Verseghy,K., Farkas,E.: Untersuchungen der Luftverunreinigung im Gebiet von Budapest mit Hilfe der Flechtenkartierung als Indikatoren. Ann Univ Sci Budapest. Sect Biol XXIV-XXVI: 163-184 (1984).

8. Farkas,E., Lôkös,L., Verseghy,K.: Lichens as indicators of air pollution in the Budapest Agglomeration. I. Air pollution map based on floristic data and heavy metal concentration measurements. Acta Bot Acad Sci Hung 31(1-4), 45-68 (1985).

9. Gallé,L.: Flechtenassoziationen in Ungarn. Móra F Múz Évk 1976-77, 429-493 (1979).

10. Farkas,E.: Investigation of the lichen flora in Budapest and in the Pilis Biosphere Reservation - distribution and bioindication. (in Hungarian) Ph.D. Thesis, Vácrátót. 1990. p. 121.

11. Farkas,E., Lôkös,L.: Distribution of the lichens Cladonia magyarica Vain., and Solorinella asteriscus Anzi in Europe. Acta Bot Fennica 150, 21-30 (1994).

12. Lôkös,L., Tóth,E.: Red list of lichens of Hungary (a proposal). In Tóth,E., Horváth,R. (eds): Proceedings of the "Research, Conservation, Management" Conference, Aggtelek, Hungary, 1-5 May 1996. Volume I, pp. 337-343.

13. Farkas,E.: Recent literature on foliicolous lichens, 1952-1985. Bot Közlem 73(1-2), 81-86 (1986)

14. Farkas,E.: Checklist of new foliicolous lichen taxa and combinations, 1952-1985. Bot Közlem 73(1-2), 8791 (1986).

15. Farkas,E., Sipman,H.J.M.: Bibliography and checklist of foliicolous lichenized fungi up to 1992. Tropical Bryology 7, 93-148 (1993).

16. Farkas,E., Sipman,H.J.M.: Checklist of foliicolous lichenized fungi. Abstracta Botanica 21(1), 173-206 (1997).

17. Farkas,E., Pócs,T. (eds): Cryptogams in the Phyllosphere: Systematics, Distribution, Ecology and Use. Proceedings of the IAB \& IAL Symposium on Foliicolous Cryptogams, 29 August-2 September 1995, Eger, Hungary. Abstracta Botanica 21(1), 1-216 (1997).

18. Farkas,E., Lôkös,L., Mázsa,K.: HPTLC-examinations on Hungarian Umbilicaria lichen species. (in Hungarian) Kitaibelia 3(2), 349-351 (1998).

19. Verseghy,K.P., Kovács-Láng,E., Mázsa,K.: Diurnal and seasonal changes of thallus water content of xerothermic lichens. Lichen Physiol Biochem 2, 23-36 (1987).

20. Tuba,Z., Csintalan,Zs., Nagy,Z., Szente,K., Kemény,G., Takács,Z., Koch,J., Badacsonyi,A., Murakeözy,P., Palicz,G., Kóbor,Sz., Ötvös,E., Bartha,S.: Symphisiology: basic thoughts and explorative examinations to a new scientific field in plant-ecology. (in Hungarian) In Fekete,G. (ed.): A közösségi ökológia frontvonalai. Scientia Kiadó, Budapest. 1998. pp. 171-196. 